\title{
Nucleic Acid Metabolism in Developing Sclerotia of the Rice Sheath Blight Fungus (Rhizoctonia solani Kühn)
}

\author{
By T. HASHIBA* AND R. C. STAPLES \\ Boyce Thompson Institute, Yonkers, New York I0701, U.S.A.
}

(Received 8 December 1975)

\begin{abstract}
SUMMARY
Sclerotia of the rice sheath blight fungus, Rhizoctonia solani Kühn, were examined for their capacity to synthesize RNA, DNA, polyadenylic acid, and for their ribonuclease and protease activities during development on a liquid medium. During maturation, sclerotia appeared to pass through three phases. The first, a period of rapid RNA synthesis, was accompanied by a decline in the content of polyA(+)RNA and a decrease in the permeability of the sclerotia. These changes suggested that the first $2 \mathrm{~h}$ were a time of reorientation of cellular metabolism. This was followed by a period of general synthesis lasting for $30 \mathrm{~h}$ which was accompanied by a further decrease in permeability, increased protease and ribonuclease activities and a rapid build-up of ribosomes. The second period terminated when protease activity declined, the other activities stabilized and the sclerotia began to turn brown. The third period, maturation, lasted for 15 days at which time the sclerotia began to float.
\end{abstract}

\section{INTRODUCTION}

Fungi can survive adverse conditions or accomplish reproduction vegetatively through a variety of spore forms, such as conidia. In addition, many fungi produce storage organs called sclerotia. These are usually formed in the soil when dense masses of hyphae arise and the short cells enlarge laterally until a compact mass of pseudoparenchymatous tissue is formed, the cells of which become polyhedral by mutual pressure. The compact mass is filled with food materials, and the outermost cells form a protective cortex which may be light in colour or, more often, brown or black. Under certain conditions, new mycelia grow out from the sclerotia to initiate fungal growth.

The morphological changes associated with differentiation of sclerotia of the rice sheath blight fungus, Rhizoctonia solani Kühn, have been examined (Hashiba, Yamaguchi \& Mogi, 1972; Hashiba \& Mogi, 1975), but few studies of the biochemical mechanisms of initiation and development of the sclerotia have been reported (Trevethick \& Cooke, I97I ; Chet, Retig \& Henis, I972; Wong \& Willetts, I974). Since the disease is spread by the sclerotia floating on water (Hashiba et al., I972), it is important to clarify the biochemical mechanisms of sclerotial development. As a first step in the characterization of these mechanisms, we describe some of the macromolecular syntheses associated with sclerotial formation by R. solani.

* Present address : Hokuriku National Agricultural Experiment Station, Joetsu, Niigata Ken, Japan. 


\section{METHODS}

Organism and media. The culture of Rhizoctonia solani Kühn used in this study was isolated from an infected rice plant as described previously (Hashiba et al., I972; Hashiba \& Mogi, 1975). Cultures were maintained on modified Murashige \& Skoog's (1962) medium which lacked kinetin, indole-2-acetic acid and inositol. Sclerotial initials were formed after 5 days at $25^{\circ} \mathrm{C}$. The time when recognizable initials appeared was taken as the zero time for observations and the ages of sclerotia were measured in relation to this. Sclerotia were similar to those formed on infected plants, including the development of buoyancy.

In experiments on the properties of sclerotia, 300 Petri dishes each containing $20 \mathrm{ml}$ modified Murashige \& Skoog's medium were inoculated centrally with $5 \mathrm{~mm}$ discs cut from the margin of a colony growing on Czapek's agar medium. At harvest, sclerotia were separated from the underlying mycelia, rinsed in ice-cold water and frozen in liquid nitrogen. The sclerotia were not stored for more than $3 \mathrm{~h}$. Sclerotial dry weight was determined by drying at $\mathrm{I} I \mathrm{I}^{\circ} \mathrm{C}$ for $\mathrm{Io} \mathrm{h}$ and weighing to the nearest $\mathrm{mg}$. For grinding, $0.5 \mathrm{~g}$ sclerotia was homogenized for 2 to 3 min with 2 vols glass beads ( $\cdot 0 \mathrm{~mm}$ ) using a Braun MSK homogenizer (Bronwill Scientific, Rochester, New York, U.S.A.) cooled with liquid $\mathrm{CO}_{2}$.

Analysis of RNA. RNA was extracted from sclerotia as described by Lovett \& Haselby (I97I). The incorporation of $\left[2,8{ }^{3} \mathrm{H}\right]$ adenosine was studied by adding $0 \cdot \mathrm{I} \mu \mathrm{Ci} / \mathrm{ml}$ medium $2 \mathrm{~h}$ before harvesting. Sclerotia were homogenized in $\mathrm{I} 5 \mathrm{ml}$ of a solution comprising $7.5 \mathrm{ml}$ TIPS [ $100 \mathrm{ml} 0.0 \mathrm{I} \mathrm{M}$-Tris $\mathrm{pH} \mathrm{7 \cdot 6,} \mathrm{I} \cdot 0 \mathrm{~g}$ triisopropylnaphthalenesulphonic acid, $6 \mathrm{~g} \mathrm{4-}$ aminosalicylic acid and $0.37 \mathrm{~g} \mathrm{KCl}$ and $7.5 \mathrm{ml}$ phenol-cresol solution $(50 \mathrm{ml}$ redistilled phenol, $7 \mathrm{ml} p$-cresol, $20 \mathrm{ml}$ water and $50 \mathrm{mg}$ 8-hydroxyquinoline). The phases were separated by centrifuging for $5 \mathrm{~min}$ and the RNA was recovered as described by Lovett \& Haselby (1971).

Extraction of adenosine. To extract $\left[2,8-{ }^{3} \mathrm{H}\right]$ adenosine which was incorporated by sclerotia but not utilized, the sclerotia were washed with cold distilled water, blotted dry and stirred for Io min with $20 \mathrm{ml}$ cold $5 \%(\mathrm{v} / \mathrm{v})$ trichloroacetic acid. After centrifuging, the supernatant solution was brought to volume and a sample was counted using liquid scintillation techniques.

Analysis of DNA. DNA was isolated by the procedure of Marmur (I96r) as modified by Villa \& Storck (1968). After labelling with $\left[2,8{ }^{3} \mathrm{H}\right]$ adenosine, sclerotia were homogenized in I $5 \mathrm{ml} \mathrm{O} \cdot \mathrm{I} 5 \mathrm{M}-\mathrm{NaCl} / \mathrm{O} \cdot \mathrm{I} \mathrm{M}-\mathrm{EDTA}$, pH 8.0, and then mixed for $30 \mathrm{~min}$ on a roller mill with an equal volume of chloroform/isoamyl alcohol/88 \% (v/v) phenol (24:I :25, by vol.). The whole mixture was centrifuged briefly in a refrigerated centrifuge at $\mathrm{I} 2000 \mathrm{~g}$, and the aqueous layer was precipitated with $14.7 \mathrm{mg}$ potassium acetate and $2.3 \mathrm{ml}$ ethanol per $\mathrm{ml}$ and stored at $-20^{\circ} \mathrm{C}$. The precipitate was dissolved in $2 \mathrm{ml}$ buffer $\left(\mathrm{pH}_{7} \cdot 6\right.$ ), containing, per $\mathrm{ml}$, io $\mu \mathrm{mol}$ Tris, Io $\mu \mathrm{mol}$ EDTA and Ioo $\mu \mathrm{mol} \mathrm{NaCl}$ (TEN buffer) and heated at $37^{\circ} \mathrm{C}$ in the presence of $2.3 \mathrm{mg} \alpha$-amylase, $5 \mu \mathrm{g}$ RNAase A and $2 \mu \mathrm{g}$ RNAase TI. After $2 \mathrm{~h}, 0.6 \mathrm{mg}$ Pronase was added and the solution incubated for another $2 \mathrm{~h}$. After cooling to room temperature, $3 \mathrm{ml}$ chloroform/isoamyl alcohol/88\% phenol (24:I :25, by vol.) was added, and the DNA was deproteinized by rolling for $5 \mathrm{~min}$. The aqueous layer formed after centrifugation was dialysed overnight at room temperature against TEN buffer.

Assay of polyadenylic acid. DNA-free RNA was extracted from sclerotia in a similar manner to that described previously (Edmonds \& Caramela, I969; Manahan, App \& Still, 1973). Sclerotia were homogenized in buffer ( $\mathrm{pH} 9{ }^{\circ}$ ) containing I00 mM-Tris- $\mathrm{HCl}, \mathrm{I}^{\circ} .0 \mathrm{~mm}$ $\mathrm{KCl}$ and $0.5 \mathrm{~mm}-\mathrm{MgCl}_{2}$, deproteinized with chloroform $/ 88 \%$ phenol (I :I, v/v), and the RNA was precipitated using potassium acetate and absolute ethanol. DNA was removed 
from the RNA extract by hydrolysis with $20 \mu \mathrm{g}$ RNAase-free DNAase. The RNA was deproteinized with an equal volume of $88 \%$ phenol, and then re-precipitated. The polyadenylate content of the RNA was determined using the hydroxylapatite procedure of Greenberg \& Perry (I972).

Ribosomes. Ribosomes were isolated by the procedure of Yaniv \& Staples (I969), and included free as well as bound ribosomes. Sclerotia were homogenized in $15 \mathrm{ml}$ buffer ( $\mathrm{pH}_{7}$.5) containing $0.45 \mathrm{M}$-sucrose, $50 \mathrm{mM}$-Tris, $5 \mathrm{mM}-\mathrm{MgCl}_{2}$ and $5 \mathrm{~mm}$-2-mercaptoethanol. The homogenate was centrifuged for $15 \mathrm{~min}$ at $20000 \mathrm{~g}$ and the supernatant solution ( $\mathrm{S}_{30}$ ) was stored at $-20^{\circ} \mathrm{C}$. Ribosomes were obtained from the $\mathrm{S} 30$ solution by centrifuging for $60 \mathrm{~min}$ at $\mathrm{I} 5 \mathrm{I} 000 \mathrm{~g}$. The pellet was resuspended in buffer $(\mathrm{pH} 7.5)$ containing $50 \mathrm{~mm}$-Tris, I $5 \mathrm{mM}-\mathrm{KCl}, 5 \mathrm{mM}-\mathrm{MgCl}_{2}$ and $5 \mathrm{~mm}-2$-mercaptoethanol, and centrifuged briefly at $20000 \mathrm{~g}$ to remove aggregates.

Ribonuclease activity. Ribonuclease activity was assayed according to the procedure of Kalnitsky, Hummel \& Dierks (1959) by measuring the amount of acid-soluble oligonucleotide liberated at $\mathrm{pH} 7 \cdot 5$, the optimum $\mathrm{pH}$ of the mycelial enzyme.

Protease activity. Protease was assayed using azure-hide powder as substrate (Rinderknecht et al., 1968). Samples ( $2 \mathrm{ml})$ were incubated with $3 \mathrm{ml}$ Tris- $\mathrm{HCl}$ buffer, $\mathrm{pH} 7 \cdot 5$, for Io min at $39{ }^{\circ} \mathrm{C}$, and then poured into test-tubes containing $15 \mathrm{mg}$ hide powder. The tubes were shaken gently to wet the powder and every 5 min thereafter. After $15 \mathrm{~min}$, the suspension was filtered through Whatman no. I filter paper, and the extinction of the filtrate at $595 \mathrm{~nm}$ was determined against a water blank. The amount of protein hydrolysed was estimated using Pronase as a standard.

Special chemicals. The following solutions were obtained from Worthington Biochemical Corp., Freehold, New Jersey, U.S.A. : $\alpha$-amylase $\left(42 \mathrm{mg} \mathrm{ml}^{-1}\right)$; pancreatic ribonuclease A $\left(9 \mathrm{mg} \mathrm{ml}^{-1}\right.$ ) heated at $80{ }^{\circ} \mathrm{C}$ for Io min; RNAase TI (I $\mathrm{mg} \mathrm{ml}^{-1}$ ); and RNAase-free deoxyribonuclease $\left(2 \mathrm{mg} \mathrm{ml}^{-1}\right)$. Azure-hide powder and Pronase (nuclease-free) were obtained from Calbiochem and diluted to $2 \mathrm{mg} \mathrm{ml}^{-1}$ with water. [2,8-3 $\mathrm{H}$ ]Adenosine (100 $\mu \mathrm{Ci} \mu \mathrm{g}^{-1}$ ) and [5- $\left.{ }^{3} \mathrm{H}\right]$ polyuridylate (Io $\mu \mathrm{Ci} \mu \mathrm{mol}^{-1}$ ) were obtained from Miles Laboratories, Kankakee, Illinois, U.S.A.; and hydroxylapatite was from Bio-Rad Laboratories.

Replication. The data used in all figures are the average of three experiments each replicated twice.

\section{RESULTS}

\section{Description of sclerotial formation}

As described previously (Hashiba et al., 1972; Hashiba \& Mogi, 1975), young sclerotia were composed of compact masses of hyphal cells which increased in size for $30 \mathrm{~h}$; at this time they began to turn brown (Fig. I). The width of the cells in the central mass increased rapidly until browning was completed at about $40 \mathrm{~h}$, while cell-wall thickness increased for I5 days.

Both fresh weight and dry weight increased steadily for $72 \mathrm{~h}$ after the appearance of sclerotial initials (Fig. 2a); but remained relatively constant (not shown) after the end of this period. 

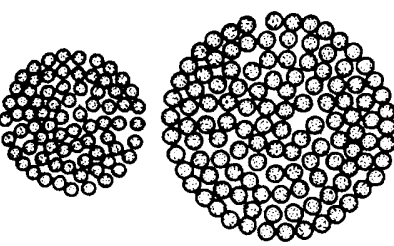

(b)

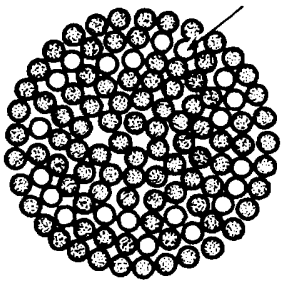

(d)

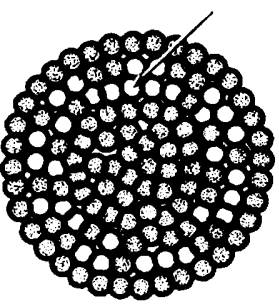

(e)

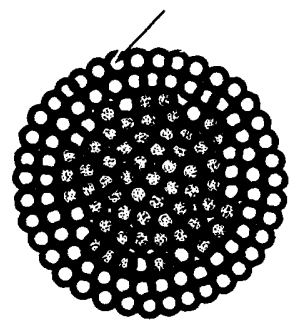

$(f)$

Fig. I. Diagram showing structural changes during sclerotium formation in Rhizoctonia solani. (a) Initiation of sclerotium; $0 \mathrm{~h}$ old. (b) Sclerotium $\mathrm{Io} \mathrm{h}$ old. (c) Sclerotium $20 \mathrm{~h}$ old. (d) Sclerotium $30 \mathrm{~h}$ old ; the browning process has begun, the sclerotium has reached its maximum size and many cells of the outer layer have emptied. (e) Sclerotium $40 \mathrm{~h}$ old ; the cells have reached their maximum width. $(f)$ Buoyant sclerotium, 15 days old ; the cell-wall thickness has reached a maximum. Arrows indicate empty cells.

\section{Changes in nucleic acids}

Total $R N A$ and $D N A$. The RNA content approximately doubled during the first $2 \mathrm{~h}$ after the appearance of sclerotia (Fig. $2 b$ ). Thereafter, the rate of increase was less rapid and was related to the increase in dry weight (Fig. $3 a$ ). The total DNA content increased steadily throughout sclerotial development (Fig. $2 b$ ).

Synthesis of RNA during the formation of sclerotia was followed by incorporation of $\left[2,8-{ }^{3} \mathrm{H}\right]$ adenosine for short periods (Fig. $2 c$ ). In spite of the steady increase in RNA content during the development of sclerotia, the amount of $\left[2,8-{ }^{3} \mathrm{H}\right]$ adenosine incorporated into RNA decreased markedly, suggesting that the sclerotia were becoming impermeable to the adenosine.

Free adenosine. The amount of ${ }^{3} \mathrm{H}$-labelled adenosine absorbed by sclerotia but not incorporated into RNA declined continuously after induction (Fig. $2 d$ ). After 20 h, very little adenosine was taken up, again suggesting that the sclerotia had become impermeable to the compound.

Polyadenylic acid. The polyadenylic acid (polyA) content was highest in RNA from mycelia (Fig. $2 e$ ). After induction, the amount of polyA rapidly declined from $26 \mu \mathrm{g} / \mathrm{mg}$ RNA to $13 \mu \mathrm{g} / \mathrm{mg}$ RNA in only $2 \mathrm{~h}$. Thus sclerotia have a lower content of polyA(+)RNA than the mycelia from which they were derived. Possibly the polyA(+)RNA in sclerotia represents a stable form of mRNA as is typical of quiescent fungal propagules.

Ribosomes. The ribosome content of sclerotia increased steadily during the $72 \mathrm{~h}$ after the appearance of initials (Fig. $2 f$ ). It increased much more rapidly than dry weight during the first $30 \mathrm{~h}$ of sclerotial development, but then the rate declined (Fig. $3 b$ ).

\section{Enzyme activities}

Ribonuclease. The activity of ribonuclease approximately doubled during the first $2 \mathrm{~h}$ (Fig. $2 g$ ). Thereafter, it continued to increase in sclerotia and reached about $\mathrm{I} \cdot \mathrm{I} 5 \mu \mathrm{g} / \mathrm{IOO}$ sclerotia after $62 \mathrm{~h}$.

Protease. After induction of sclerotia, protease activity increased about $4 \cdot 5$-fold and reached a maximum at $30 \mathrm{~h}$ (Fig. $2 h$ ). The enzyme activity then declined and could not be detected after $60 \mathrm{~h}$. 

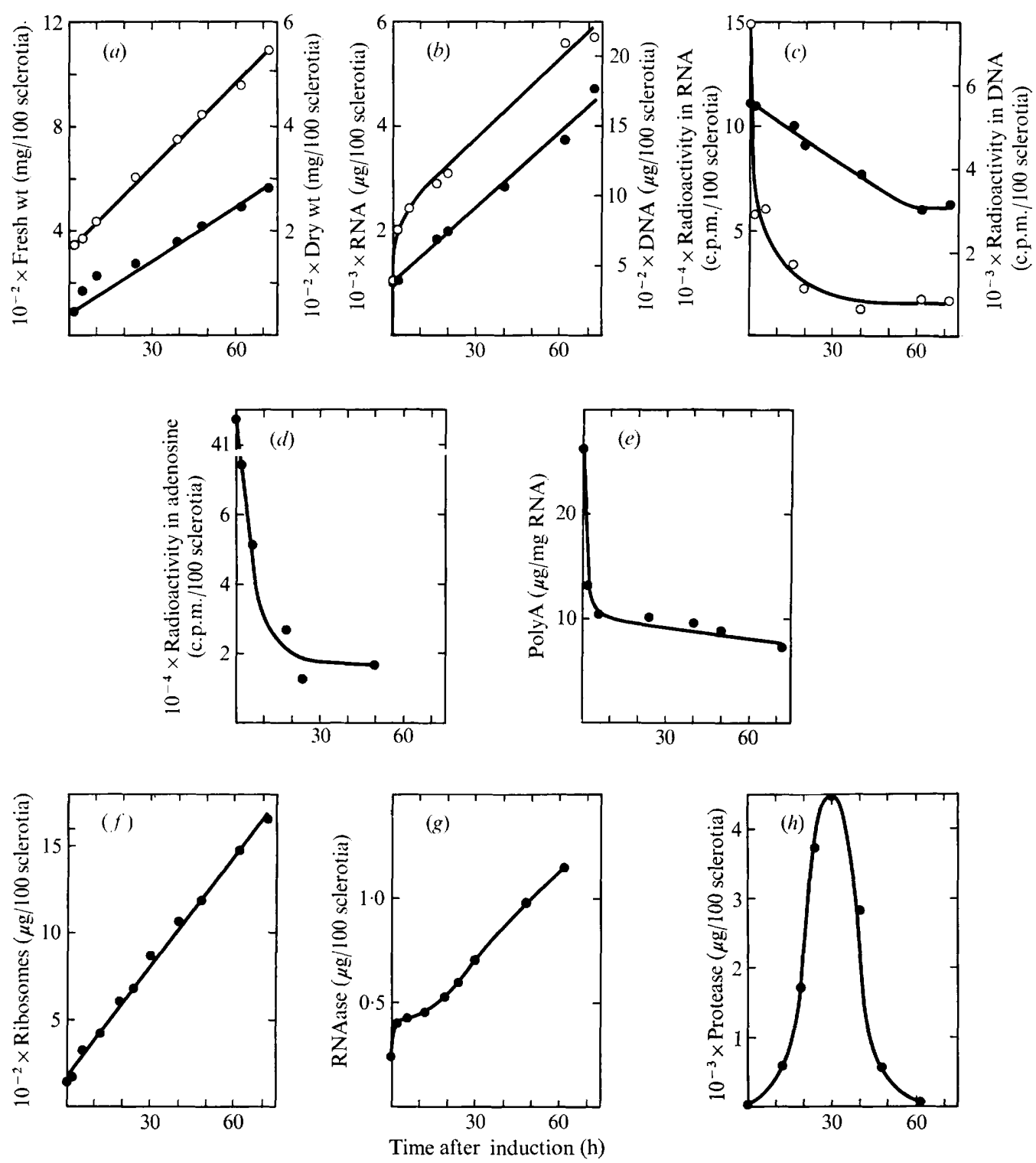

Fig. 2. Changes in several parameters during the development of sclerotia of $R$. solani. (a) Fresh weight $(\bigcirc)$ and dry weight $(O)$. (b) RNA ( $\bigcirc)$ and DNA (O) contents. (c) Incorporation of adenosine into RNA (O) and DNA (O). (d) Content of free ${ }^{3} \mathrm{H}$-labelled adenosine. (e) Content of polyA(+)RNA. $(f)$ Ribosome content. $(g)$ Ribonuclease activity. $(h)$ Protease activity.

\section{DISCUSSION}

In $R$. solani, sclerotia first appeared as a more or less compact mass of hyphal cells (Hashiba et al., 1972; Hashiba \& Mogi, 1975). The cells in the central mass increased in diameter and many mitochondria and ribosomes were present. After $30 \mathrm{~h}$, when the size of sclerotia and the cell width reached a maximum, the amount of mitochondria and ribosomes in individual cells appeared to be reduced. Cells in the central mass accumulated glycogen, 


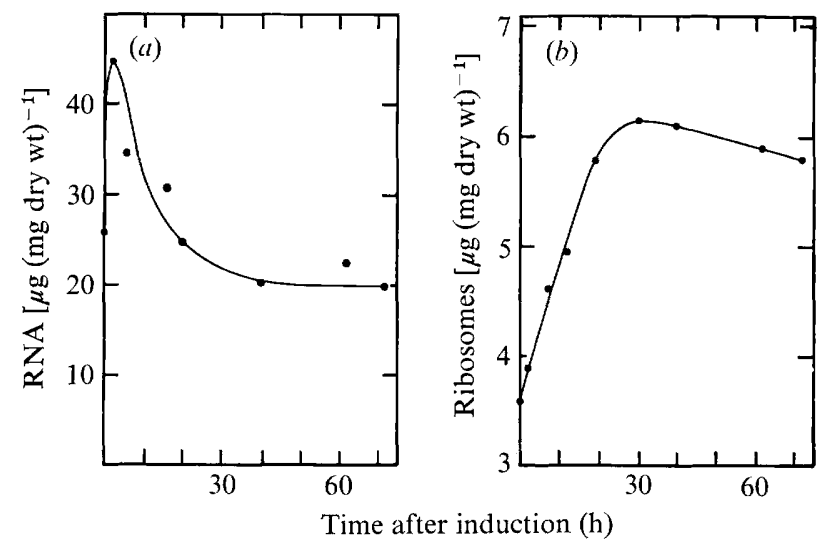

Fig. 3. Changes in (a) RNA and (b) ribosome contents, expressed on a dry weight basis, during the development of sclerotia of $R$. solani.

while cells in the outer layer began to lose their contents. After I 5 days, the sclerotia became buoyant. Our studies were confined to the first 3 days after induction, and so did not involve the development of buoyancy.

Our data suggest that sclerotia pass through three characteristic periods of development after induction. First, there is an intense $2 \mathrm{~h}$ period of RNA synthesis during which the polyA(+)RNA content declines and the cells become impermeable. Secondly, there is a general period of RNA synthesis during which the activities of protease and RNAase increase. Protease activity reaches a maximum at $30 \mathrm{~h}$; and then the third period begins as the cells in the outer layers begin to empty. The 3oth hour also marks the time when impermeability reaches a maximum, and the rate of ribosome accumulation has slowed. The period after $30 \mathrm{~h}$ continues for 15 days until the sclerotia become buoyant. This buoyancy is an important property for the spread of the disease (Hashiba \& Mogi, 1975). It will be of interest to learn how these three rather distinct periods of sclerotial development are co-ordinated when the sclerotia appear to be impermeable to the external environment.

We thank Dr Zohara Yaniv and Dr V. Macko for valuable discussions, and Ms Lucille Laccetti for her capable technical help. The work was supported in part by a grant from the Science and Technology Agency, Tokyo, Japan.

\section{REFERENCES}

Chet, I., Retig, N. \& Henis, Y. (1972). Changes in total soluble proteins and in some enzymes during morphogenesis of Sclerotium rolfsii. Journal of General Microbiology 75, 45I-456.

Edmond, M. \& CARAmela, M. G. (I969). The isolation and characterization of adenosine monophosphaterich polynucleotides synthesized by Ehrlich ascites cells. Journal of Biological Chemistry 244, I3 I 4-I 324.

Greenberg, J. R. \& PerRy, R. P. (1972). The isolation and characterization of steady-state labeled messenger RNA from L-cells. Biochimica et biophysica acta 287, 36I-366.

Hashiba, T. \& Mogi, S. (I975). Developmental changes in sclerotia of the rice sheath blight fungus. Phytopathology 65, 159-I62.

Hashiba, T., YamaguChI, T. \& Mogi, S. (1972). Biological and ecological studies on the sclerotium of Pellicularia sasakii (Shirai) S. Ito. I. Floating on the water surface of sclerotium. Annals of the Phytopathological Society of Japan $\mathbf{3}^{8}, 4 \mathrm{I} 4-425$.

Kalnitsky, G., Hummel, J. P. \& Dierks, C. (1959). Some factors which affect the enzymatic digestion of ribonucleic acid. Journal of Biological Chemistry 234, I5 I 2-15I6. 
LOVEtT, J. S. \& HaSelby, J. A. (197I). Molecular weights of the ribosomal ribonucleic acid of fungi. Archiv für Mikrobiologie 80, I9I-204.

Manahan, C. O., App, A. A. \& Still, C. C. (I973). The presence of polyadenylate sequences in the ribonucleic acid of a higher plant. Biochemical and Biophysical Research Communications 53, 588-595.

MARMUR, J. (196I). A procedure for the isolation of deoxyribonucleic acid from micro-organisms. Journal of Molecular Biology 3, 208-2 I 8 .

Murashige, T. \& Skoog, F. (1962). A revised medium for rapid growth and bioassays with tobacco tissue cultures. Physiologia plantarum 15, 473-497.

Rinderknecht, H., Geokas, M. C., Silverman, P. \& Haverback, B. J. (1968). A new ultrasensitive method for the determination of proteolytic activity. Clinica chimica acta 21, 197-203.

TreVETHICK, J. \& COOKE, R. C. (I97I). Effects of some metabolic inhibitors and sulphur-containing amino acids on sclerotium formation in Sclerotium rolfsii, S. delphinii and Sclerotinia sclerotiorum. Transactions of the British Mycological Society 57, 340-342.

Villa, V. D. \& STORCK, R. (1968). Nucleotide composition of nuclear and mitochondrial deoxyribonucleic acid of fungi. Journal of Bacteriology 96, $184-190$.

WonG, A.-L. \& WiLletTs, H. J. (1974). Polyacrylamide-gel electrophoresis of enzymes during morphogenesis of sclerotia of Sclerotinia sclerotiorum. Journal of General Microbiology 81, I0I-I09.

YANIV, Z. \& STAPLES, R. C. (I969). Transfer activity of ribosomes from germinating uredospores. Contributions. Boyce Thompson Institute for Plant Research 24, 156-163. 